\title{
1. General principles of law recognized by civilized nations: method, inductive-empirical analysis and (more) 'scientific' results
}

\section{Marija Đorđeska*}

\subsection{INTRODUCTION}

Lassa Oppenheim wrote in 1921 that '[h]e [or she] who would portray the future of international law must first of all be exact in his [or her] attitude towards its past and present'. ${ }^{1}$ His earlier quasi-manifesto on The Science of International Law in $1908^{2}$ inspired the adoption of a more scientific approach in researching a well-known 'mystery' of international law, namely the 'general principles of law recognized by civilized nations'3 (the 'general principles') as codified in Article 38(1)(c) of the Statute of the International Court of Justice.

Article 38(1) provides that ' $[\mathrm{t}] \mathrm{he}$ Court ... shall apply ... (c) the general principles of law recognized by civilized nations' ${ }^{4}$ Although part of the Court's Statute since 1920, scholars have not yet come to an agreement as to what general principles are. ${ }^{5}$ Some authors even argue that general

* I would like to thank Sam Ghazizadeh, Mariam Ghazaryan and Kit De Vriese for their help in finalising the article. I would also like to thank Brill for the permission to use the figures in the forthcoming, General Principles of Law Recognized by Civilized Nations (1922-2018) (Brill, Leiden 2020).

1 Lassa Oppenheim, The Future of International Law (Humphrey Milford, New York 1921) 1.

2 Lassa Oppenheim, 'The Science of International Law: Its Task and Method' [1908] Am. J. Int'1 L. 2, 313.

3 Statute of the International Court of Justice 1945, article 38(1)(c).

4 Statute of the International Court of Justice 1945, article 38(1).

5 See e.g., Alain Pellet, 'Article 38' in Andreas Zimmerman, Karin OellersFrahm, Christian Tomuschat and Christian J. Tams (eds), The Statute of the International Court of Justice: A Commentary (Oxford University Press, Oxford 2012) 766; Catherine Redgwell, 'General Principles of International Law' in Stefan 
principles do not belong among the sources of international law. ${ }^{6}$ The combination of the empirical research and inductive analysis presented in this chapter seeks to (1) provide a more accurate and objective image of what general principles are and (2) contribute towards an agreement on the definition of general principles, a century after their inception as part of Article 38(1)(c).

Although there has been much written about general principles, ${ }^{7}$ there is no up-to-date research that would comprehensively analyse the role of general principles in the jurisprudence of the Permanent Court of International Justice (the 'PCIJ') and the International Court of Justice (the 'ICJ'). ${ }^{8}$ Literature that addresses the Court's reliance on general principles usually does not provide an explanation as to what was the research methodology that led to scholars' conclusions on general principles.

Similarly, the Court does not discuss nor disclose its methodology of ascertaining general principles in its publicly available decisions. ${ }^{9}$ The Court is even more silent as to how it ascertains general principles than it is in relation to ascertaining norms of customary international law. ${ }^{10}$ And rightly so. Due to the judicial nature of general principles, the Court does not elaborate extensively on research mechanisms that it may employ in its in camera deliberations. ${ }^{11}$ The Court is not a scientific body nor an

Vogenauer and Stephen Weatherill (eds), General Principles of Law: European and Comparative Perspectives (Hart Publishing, Oxford 2017) 9; Maurice Mendelson, 'The Formation of Customary International Law' in offprint from the (1998) 272 Recueil des Cours de l'Académie de Droit International 195.

6 See e.g., Jean d'Aspremont, 'What Was Not Meant to Be: General Principles of Law as a Source of International Law' in Riccardo Pisillo Mazzeschi and Pasquale De Sena (eds), Global Justice, Human Rights, and the Modernization of International Law (Springer, Cham 2018) 164.

7 See e.g., Marcelo Kohen and Berenice Schramm, 'General Principles of Law' in [2018] Oxford Bibliographies <https://oxfordindex.oup.com/viewindexcard/10.1 093\$002fobo\$002f9780199796953-0063> accessed 20 August 2019.

8 Both courts are referred to in this article as 'the Court'.

9 See also Fabian Raimondo, General Principles of Law in the Decisions of International Criminal Courts and Tribunals (Brill, Leiden 2008) 21-2.

10 Stefan Talmon, 'Determining Customary International Law: The ICJ's Methodology between Induction, Deduction and Assertion' [2015] Eur. J. Int'l L. 418-19.

11 See also Fabian Raimondo, General Principles of Law in the Decisions of International Criminal Courts and Tribunals (Brill, Leiden 2008) 22. Raimondo notes that 'the issue of the suitability of general principles of law for regulating international law issues normally does not arise in judgments and advisory opinions ... [w]hether the issue has come up during the deliberations of both 
academic institution with an opportunity to write about any subject to its liking. ${ }^{12}$ Instead, scholars are implicitly mandated to analyse the Court's jurisprudence and international law for the Court's use. However, so far, neither scholarship nor the Court's jurisprudence clearly indicates what the Court's parameters of ascertaining general principles are. Scholars have not agreed on a definition of general principles, nor has the method of their ascertainment been set.

This chapter presents the methodology that led to an objective definition of general principles based on the observation of international jurisprudence (and to the exclusion of scholarly opinions). The wish to secure results independent of the current (and largely unfruitful) doctrinal discussions about general principles inspired the merging of the empirical research method with the inductive analysis of the word 'principle' as it appears in the Court's jurisprudence.

This method yielded measurable data and gave rise to a theory about general principles based solely on the Court's jurisprudence (as opposed to relying on doctrinal positions) that in 2018 counted 215 decisions (i.e., judgments and advisory opinions). ${ }^{13}$ The aim of this Herculean task was to provide objectively verifiable data that would one day enable the international community to reach an agreement on one of the three types of sources of international law - the so-called 'general principles of law recognized by civilized nations' ${ }^{14}$

\section{2 'SCIENTIFIC' APPROACH}

Neither the Court's jurisprudence nor doctrine provide any guidance on how to ascertain a general principle. There is also no definition of what general principles are. The number of disagreements among the scholars in relation to general principles stem (among others) from the absence of

international courts is uncertain, given that these are private and are to remain secret'. Id.

12 See also e.g., Stefan Talmon, 'Determining Customary International Law: The ICJ's Methodology between Induction, Deduction and Assertion' [2015] Eur. J. Int'l L. 434 (noting that 'the Court does not offer any (inductive or deductive) reasoning but simply asserts the law as it sees fit').

13 Decisions on preliminary objections and the Court's decisions on applications to intervene were considered as 'judgments'. Cases that were joined (the North Sea Continental Shelf and South West Africa cases) were considered as one unit for the purpose of this statistic. Orders for provisional measures or compensation were not included as part of this research.

14 Statute of the International Court of Justice 1945, article 38(1)(c). 
an agreed-upon definition and a method of ascertaining them. ${ }^{15}$ While some scholars advocate resorting solely to the comparativist approach in ascertaining general principles to the exclusion of other methods, ${ }^{16}$ the Court is yet to invoke a comparative analysis relative to general principles in its publicly available decisions. ${ }^{17}$

The two seminal works on this subject, Bin Cheng's 1953 General Principles of Law as Applied by International Courts and Tribunals and Fabian Raimondo's 2008 General Principles of Law, Judicial Creativity, and the Development of International Criminal Law, survey the international judicial application of general principles, but do not discuss the Court's methodology in ascertaining them. Neither Cheng nor Raimondo explain how they arrived at the conclusion that a specific norm the Court relied upon was in fact a general principle within the meaning of Article 38(1)(c) of the Court's Statute. ${ }^{18}$

15 Jean d'Aspremont, 'What Was Not Meant to Be: General Principles of Law as a Source of International Law' in Riccardo Pisillo Mazzeschi and Pasquale De Sena (eds), Global Justice, Human Rights, and the Modernization of International Law (Springer, Cham 2018) 178 (observing that 'most authors ... have turned a blind eye to the above-mentioned methodological problems'). An exception is Yotova, who dedicated her research to 'seek[ing] to identify the appropriate methodology for ascertaining the existence of the controversial "general principles of law". Rumiana Yotova, "Challenges in the Identification of the "General Principles of Law Recognized by Civilized Nations": The Approach of the International Court' [2017] Can. J. Comp. \& Contemp. L. 269.

16 See e.g., Petros Vallindas, 'A Plea for an International Legal Science' [1959] Int'1 \& Comp. L. Q. 619; Georg Schwarzenberger, 'The Fundamental Principles of International Law' in (1955) 87 Recueil des Cours de l'Académie de Droit International 193; Rumiana Yotova, 'Challenges in the Identification of the "General Principles of Law Recognized by Civilized Nations": The Approach of the International Court' [2017] Can. J. Comp. \& Contemp. L. 272-3 (enumerating among the comparativists also Oppenheim, Lauterpacht, Grapin, Schlesinger and Herczegh).

17 Alain Pellet, 'Article 38' in Andreas Zimmerman, Karin Oellers-Frahm, Christian Tomuschat and Christian J. Tams (eds), The Statute of the International Court of Justice: A Commentary (Oxford University Press, Oxford 2012) 771-2 (noting that 'the Court asserts the existence of the general principles of law without taking pains to demonstrate it'); Rumiana Yotova, 'Challenges in the Identification of the "General Principles of Law Recognized by Civilized Nations": The Approach of the International Court' [2017] Can. J. Comp. \& Contemp. L. 314. Cf. Artur Kozłowski, 'Systematicity of General Principles of (International) Law: An Outline' [2017] Polish Y. Int'1 L. 230 (referring to the 'comparativist effort of the judge').

18 Among the general principles identified by Cheng, but not also mentioned in the Court's jurisprudence, is the general principle of competence. Bin Cheng, General Principles of Law as Applied by International Courts and Tribunals (Stevens \& Sons 1953; reprinted by Cambridge University Press, London 1987) 261. 
For example, Raimondo refers to the "principle that "proof may be administered by means of circumstantial evidence", which the Court allegedly applied in the Corfu Channel case. ${ }^{19}$ Raimondo justifies his assessment that this norm is a general principle because it 'filled the gap left by the absence of relevant provisions in the Rules of the Court' ${ }^{20}$ However, the Court did not refer to this norm as a 'principle' at any point in its jurisprudence. Raimondo's work provides a case-by-case textual interpretation of eight ICJ decisions rather than setting out a potential overall methodology of ascertaining general principles. $\mathrm{He}$ speculates however, that what points to the existence of a general principle is the Court's statement that this norm is '[admitted] in "all systems of law." ${ }^{21}$ This assessment, although revealing one of the Court's possible approaches of ascertaining new procedural rules, does not also provide a clear method through which Raimondo researched general principles.

The drafting history of the Court's Statute reveals that in 1920 the Advisory Committee of Jurists drafted a third source of international law as part of the draft Article 35 (now Article 38) to enable the thenforthcoming Permanent Court of International Justice to render decisions in accordance with international law without declaring a non liquet. ${ }^{22}$ The third source of international law, originally incepted as 'rules of international law as recognized by the legal conscience of civilized nations ${ }^{23}$ and

Cheng's research was also not limited only to the PCIJ and ICJ jurisprudence. Id., xxxi-xliii.

19 Fabian Raimondo, General Principles of Law in the Decisions of International Criminal Courts and Tribunals (Brill, Leiden 2008) 28.

20 ibid.

21 ibid., 29.

22 Procès-Verbaux of the Proceedings of the Committee, 16 June-24 July 1920, with Annexes, Permanent Court of International Justice (ser. D) 306 (Annex no. 3) and 344 (Annex no. 1). See also Ole Spiermann, "Who Attempts Too Much Does Nothing Well": The 1920 Advisory Committee of Jurists and the Statute of the Permanent Court of International Justice' [2003] Brit. Y. of Int'1 L. 242 (noting that the Advisory Committee did not consider the final draft of Article 35 a success); Ole Spiermann, 'The History of Article 38 of the Statute of the International Court of Justice: “A Purely Platonic Discussion”?' in Samantha Besson and Jean d'Aspremont (eds), The Sources of International Law: The Oxford Handbook of the Sources of International Law (Oxford University Press, Oxford 2017) 171 (noting that Ricci-Busatti and de Lapradelle commented that '[the inclusion of paragraph 3] did not necessarily exclude the possibility of a non liquet').

23 Procès-Verbaux of the Proceedings of the Committee, 16 June-24 July 1920, with Annexes, Permanent Court of International Justice (ser. D) 306 (Annex no. 3). 
later termed 'general principles of law recognized by civilized nations', ${ }^{24}$ was not source of international law already in existence but rather the result of a consensus of the ten-member Committee.

\subsubsection{Step 1: Extrapolating the Word 'Principle' from Article 38(1)(c)}

The first step towards creating a method of ascertaining general principles was to consider the text of Article 38(1)(c) of the Court's Statute. Article 38(1)(c) provides that the Court may rely on 'general principles of law recognized by civilized nations' in resolving international disputes. ${ }^{25}$ In the absence of any previously known methodologies of researching general principles, the decision was made to extrapolate the word 'principle' from the formulation of Article 38(1)(c) and research its use in all of the Court's 215 decisions rendered between 1922 and 2018.

There are several reasons for focusing the research on the Court's reliance only on the word 'principle' to the exclusion of the remainder of the Article 38(1)(c) formulation. First, the Court rarely, if ever, used in its decisions the entire formulation provided in Article 38(1)(c), namely, 'general principles of law recognized by civilized nations' ${ }^{26}$ However, the Court not opting to rely on the entire Article 38(1)(c) formulation does not suggest that it also never invoked general principles. The Court's jurisprudence demonstrates that it does not cite Article 38(1) formulations when referring to any source of international law, including when referring to treaties or customary international law. Second, some terms in Article 38(1)(c) do not add any particular value. For example, the words 'of law' are redundant because the Court is tasked with applying international $l a w^{27}$ and, therefore, all principles invoked by the Court when applying the Article 38(1) sources are also legal principles.

Similarly, the scope of the research was not limited to considering solely 'general principles', although one could argue that the adjective 'general' most accurately describes the third source of international law. General principles - although termed as general - may be also quite specific. For example, the 'general principle that the words must be interpreted in the sense in which they would normally have in their natural and ordinary meaning' is quite specific, ${ }^{28}$ especially when compared to a fellow 'general

24 Procès-Verbaux of the Proceedings of the Committee, 16 June-24 July 1920, with Annexes, Permanent Court of International Justice (ser. D) 344 (Annex no. 1).

25 Statute of the International Court of Justice 1945, article 38(1)(c).

26 Statute of the International Court of Justice 1945, article 38(1)(c).

27 Statute of the International Court of Justice 1945, article 38(1) chapeau.

28 The general principle is in its entirety as follows: 'general principle that 
principle of good faith' ${ }^{29}$ Thus, instances when the Court did not rely on, the term 'general' when referring to 'principles' did not automatically mean that the Court refused to apply an Article 38(1)(c) norm. The Court does not invoke the adjective 'general' in its jurisprudence also when relying on norms of customary international law, although the Article 38(1)(b) formulation provides that 'international custom [is] evidence of a general practice accepted as law'. ${ }^{30}$

On a side note, scholars tend to differentiate between general principles of law and general principles of international law. Regardless of the basis upon which the Court ascertains general principles (domestic or other), all general principles are because of international law, the Court's function is to decide disputes 'in accordance with international law'. ${ }^{31}$

\subsubsection{Step 2: Surveying the Court's Jurisprudence for Reference to 'Principle'}

The second step in discerning a new method was to survey all 215 decisions (i.e., judgments and advisory opinions) rendered between 1922 and 2018. This step required setting up a personal database of the Court's jurisprudence, onto which each PCIJ and ICJ decision was downloaded. The personal database is not publicly available and its publication is no longer needed due to the existence of Jus Mundi. ${ }^{32}$

Orders and judges' opinions were not surveyed for the references to the word 'principle'. Judges' opinions do not carry as much weight as the decisions taken by the Court as a whole do and their inclusion did not justify the potential five- or ten-fold increase of the material to be surveyed

the words must be interpreted in the sense in which they would normally have in their natural and ordinary meaning in their context, unless such interpretation would lead to something unreasonable or absurd'. See e.g., Polish Postal Service in Danzig [1925] P.C.I.J. (B/11) [39]-[40]; Competence of the General Assembly for the Admission of a State to the United Nations [1950] I.C.J. 4 [8].

29 See e.g., Certain German Interests in Polish Upper Silesia (Merits) [1926] P.C.I.J. (A/7) [42]; Conditions of Admission of a State to Membership in the United Nations (Article 4 of the Charter) [1948] I.C.J. 57 [63].

30 Statute of the International Court of Justice 1945, article 38(1)(b) (emphasis added).

31 Statute of the International Court of Justice 1945, article 38(1) chapeau.

32 Jus Mundi provides a timely and welcome online database of international legal materials and enables an effortless word-specific search with the possibility to filter the (sometimes overwhelming) results. See Jus Mundi <https://jusmundi. com> accessed 4 March 2019. 
and analysed. Additionally, judges' opinions as to what general principles are - although very informative - were not cited by the Court.

Excluded from the survey were also States' references to general principles that were mentioned in the Court's reasoning. Because States' assertion as to whether a certain general principle exists did not play a major role in the Court's reasoning (due to the general principle of jura novit curia or 'the Court knows the law'), ${ }^{33}$ their claims relating to general principles were also not included in the research.

\subsubsection{Step 3: Weeding 'Principles' from 'Principles'}

It became apparent early on in the research that not all Court references to 'principles' were tied to a particular norm (whether in the form of a principle or a rule). Step 3 entailed differentiating between the Court's references to 'principle' that corresponded to a norm (also referred to here as 'principle'-norm) and those references to 'principle' that were simply word-fillers. Only 'principle'-norms were considered as the Court's references to general principles within the meaning of Article 38(1)(c) of its Statute.

Most common examples of the Court's reference to 'principle' as a word-filler are its references to 'in principle' and 'as a matter of principle'. While the former usually pointed to an exception to a particular norm (belonging to any of the three sources of international law) the latter expression contributed to neither setting up nor clarifying a particular norm. These and other word-fillers containing the word 'principle' were not considered further.

The hypothesis was that if the Court used the word 'principle' at least once in relation to a specific norm, it ascertained an Article 38(1)(c) norm. For example, the Court in Land, Island and Maritime Frontier Dispute relied on the general principle of uti possidetis juris by noting that 'when the principle of jus possidetis juris is involved, the jus referred to is not international law but the constitutional or administrative law of the pre-independence sovereign' ${ }^{34}$ Similarly, the Court in Land and Maritime Boundary between Cameroon and Nigeria relied on the general principle of intertemporal law when noting that 'the principle of intertemporal law

33 Aaron X. Fellmeth and Maurice Horwitz, Guide to Latin in International Law (Oxford University Press, Oxford 2009) 147.

34 Land, Island and Maritime Frontier Dispute [1992] I.C.J. 351 [ $₫ 333]$ (emphasis added). 
requires that the legal consequences of the treaties concluded at the time in the Niger delta be given effect today'. ${ }^{35}$

Not all Latin maxims used by the Court in its decisions automatically qualified as general principles. ${ }^{36}$ For example, the Court in the South West Africa cases referred to actio popularis - a Latin maxim meaning 'action at law of the people'37 - but did not declare it to be part of positive international law (i.e., law the Court would resort to in rendering a decision). The Court clearly noted that

although a right of this kind [the right of residents in any member of a community to take legal action in vindication of a public interest, i.e., actio popularis] may be known to certain municipal systems of law, it is not known to international law as it stands at present: nor is the Court able to regard it as imported by the 'general principles of law' referred to in Article 38, paragraph 1 (c), of its Statute. ${ }^{38}$

General principles ascertained by other international tribunals, but not also relied upon by the Court, were outside the scope of this research and were consequently not analysed. For example, while the ne bis in idem principle is well known in the jurisprudence of international criminal courts, the Court as a whole had not made a use of it in its decisions. ${ }^{39}$ Therefore, ne bis in idem was not considered a general principle that would be present within the Court's jurisprudence.

35 Land and Maritime Boundary between Cameroon and Nigeria [2002] I.C.J. 303 [ [1205] (emphasis added).

${ }_{36}$ See e.g., Lassa Oppenheim, The Future of International Law (Clarendon Press, Oxford 1921) 35; Hersch Lauterpacht, Private Law Sources and Analogies of International Law (Longmans, Green \& Co., London 1927) 178, 225. Cf. Gerald Fitzmaurice, The Law and Procedure of the International Court of Justice, vol II (2nd edn, Cambridge University Press, Cambridge 1993) 619-20, 623-4 (considering that all Latin maxims are automatically general principles).

37 'A right of action belonging to the international community as a whole or to any person, usually arising from a violation of a duty erga omnes'. Aaron X. Fellmeth and Maurice Horwitz, Guide to Latin in International Law (Oxford University Press, Oxford 2009) 12.

38 South West Africa [1966] I.C.J. 6 [\$88].

39 Ne bis in idem had been mentioned by the Court's judges in their opinions. See Malgosia Fitzmaurice, 'Customary Law, General Principles, Unilateral Acts' in Benjamin Samson and Edgardo Sobenes Obregon (eds), Nicaragua before the International Court of Justice (Springer, Cham 2018) 262. 


\subsubsection{Step 4: Inductive Analysis}

The inductive analysis began after a large sample of the Court's references to a 'principle'-norm had been collected. The initial assessment of a sample enabled the preliminary creation of categories based on the commonalities of the Court's references to 'principle'-norms. The references were classified under different headings related to their function, nature and content. The categorizations changed in the process of analysing all Court's references to 'principle'-norms. Questions that arose during the research and helped shape the relevant categorisation were as follows: did the Court rely on a 'principle'-norm of a particular subject-matter of international law?, did the Court's reliance on the word 'principle' imply any particular function of that 'principle'?, and what was the relationship between the 'principle' and another norm belonging to any other source of international law?

\subsubsection{Step 5: Provisional Definition of General Principles}

Talmon defines induction as 'a process of going from the specific to the general [and] . . a process of observation and empirical generalization'.$^{40}$ Employing the inductive analytical process in observing general principles meant that the analysis began without a definition of general principles or a theory about general principles that the research would prove. Instead, processing of the data obtained from the Court's jurisprudence enabled the crafting of a provisional definition of general principles. The provisional definition evolved in the course of the research to accommodate the entirety of the Court's references to 'principle'-norms.

The normative findings related to the definition of general principles served as the basis for further theoretical exploration of the types, underpinnings, content and other modalities of general principles, including their relationship to the other two sources of international law (treaties and customary international law).

40 Stefan Talmon, 'Determining Customary International Law: The ICJ's Methodology between Induction, Deduction and Assertion' [2015] Eur. J. Int'l L. 420 (considering deduction as 'a process of going from the general to the specific' and a process complementary to induction). See also Anthony D'Amato, 'The Inductive Approach Revisited' [1996] Indian J. Int'1 L. 510 (noting that induction is a 'logical process . . . [of] derivation of generalizations from a number of specific instances'). 


\subsubsection{Step 6: Addressing the Challenges}

One of the challenges that arose during the research was the Court's inconsistent reference to the same norm as a 'principle' in the same decision or over the course of its jurisprudence. For example, in Territorial and Maritime Dispute in the Caribbean Sea, the Court referred to the norm that land dominates the sea as a 'principle' in paragraph 126 but did not label the notion as a 'principle' in paragraph 113 of the same decision. ${ }^{41}$

Instances when the Court would refer to a norm only once as a 'principle' while omitting the prefix 'principle' in other paragraphs of the same decisions or in other decisions were considered in this research sufficient for the norm's classification as a general principle within the meaning of Article 38(1)(c). As a hypothetical example, if the Court in its 1985 decision referred to the 'principle of X', but referred to the 'doctrine of $X$ ' in a 2001 decision and only to ' $X$ ' in 1950, all three hypothetical references (in 1950, 1985 and in 2001) were considered as references to the general principle of X. Similarly, general principles identified solely by scholars but not also mentioned at least once as 'principles' in the Court's jurisprudence were not considered as Article 38(1)(c) norms.

Adopting the approach of considering one reference to the word 'principle' in the Court's jurisprudence as sufficient for finding an Article 38(1) (c) norm was necessary for documenting the continuation and evolution of a particular norm over the course of the Court's jurisprudence, regardless of the Court's (inconsistent) use of the word 'principle' in describing the same norm. For example, the PCIJ referred to estoppel as a 'principle' in the 1929 Serbian Loans case, ${ }^{42}$ but not also in the North Sea Continental Shelf case. $^{43}$ However, in both decisions the Court relied on the same norm (estoppel). Thus, estoppel was classified in this research as a general principle because the Court referred to it once as a 'principle'. The Court's omission of the word 'principle' in the North Sea Continental Shelf case (among other decisions referring to estoppel) did not alter the norm's status as a general principle.

41 Territorial and Maritime Dispute between Nicaragua and Honduras in the Caribbean Sea [2007] I.C.J. 659 [ๆ113] [ [126].

42 Serbian Loans [1929] P.C.I.J. (A/20) [38]-[39].

43 North Sea Continental Shelf [1969] I.C.J. 3 [ๆ30]. 


\subsection{INDUCTIVE-EMPIRICAL ANALYSIS}

The empirical research and inductive analysis yielded a definition of general principles, four conclusions on their nature, a classification of general principles into three types (substantive, procedural and interpretative) and the finding that the Court may ascertain general principles in different basis or bases (domestic law, international law and/or by relying on its judicial authority to decide). The empirically inductive method led to a new normative theory of general principles and their interaction with the remaining two sources of international law - customary international law and treaties. ${ }^{4}$

Scholarly findings and literature did not play a major role in setting up the research method or in coming to the research results. The lack of scholarly consensus on the topic contributed to moving away from relying on scholarly work that would inevitably lead to siding with a particular already-adopted view. Scholarly work, although providing a wealth of opinions is mostly not substantiated with primary sources (i.e., Court's decisions). When scholars do rely on judicial decisions, their results are not based on a comprehensive research of the entire jurisprudence.

Doctrine was considered after the conclusion of the research and served the purpose of providing a contrast to the findings of the empirically inductive research that focused solely on considering the Court's jurisprudence. For example, unlike the assertion of some scholars that the Court relied on general principles rarely or never, ${ }^{45}$ the results of the empirical

44 The author's detailed findings are in the forthcoming monograph General Principles of Law Recognized by Civilized Nations (1922-2018) (Brill, Leiden, 2020).

45 Hugh Thirlway, The Sources of International Law (Oxford University Press, Oxford 2014) 102; Géza Herczegh, General Principles of Law and the International Legal Order (Akadémiai Kiadó, Budapest 1969) 31; Izabela Skomerska-Muchowska, 'Some Remarks on the Role of General Principles in the Interpretation and Application of International Customary and Treaty Law' [2017] Polish Y. Int'l L. 256; Mahmoud Cherif Bassiouni, 'A Functional Approach to "General Principles of International Law"” [1990] Mich. J. Int'1 L. 791 (noting that '[a]n examination of the two court's decisions reveals that the judges have only sparingly employed "General Principles" in their opinions'); Roman Kwiecień, "General Principles of Law: The Gentle Guardians of Systemic Integration of International Law' [2017] Polish Y. Int'1 L. 237. But see Mahmoud Cherif Bassiouni, 'A Functional Approach to "General Principles of International Law" [1990] Mich. J. Int'l L. 792 (observing that '[i]n a number of cases, the court did resort to and apply, "General Principles"'); Manley Ottmer Hudson, The Permanent Court of International Justice 1920-1942: A Treatise (The Macmillan 
and inductive research demonstrate quite the opposite. Out of the total 215 decisions (judgments and advisory opinions) that the Court rendered between 1922 and 2018, 165 decisions contained a reference to at least one general principle. In other words, the Court referred to general principles in 76.7 per cent of its decisions. (See Figure 1.1)

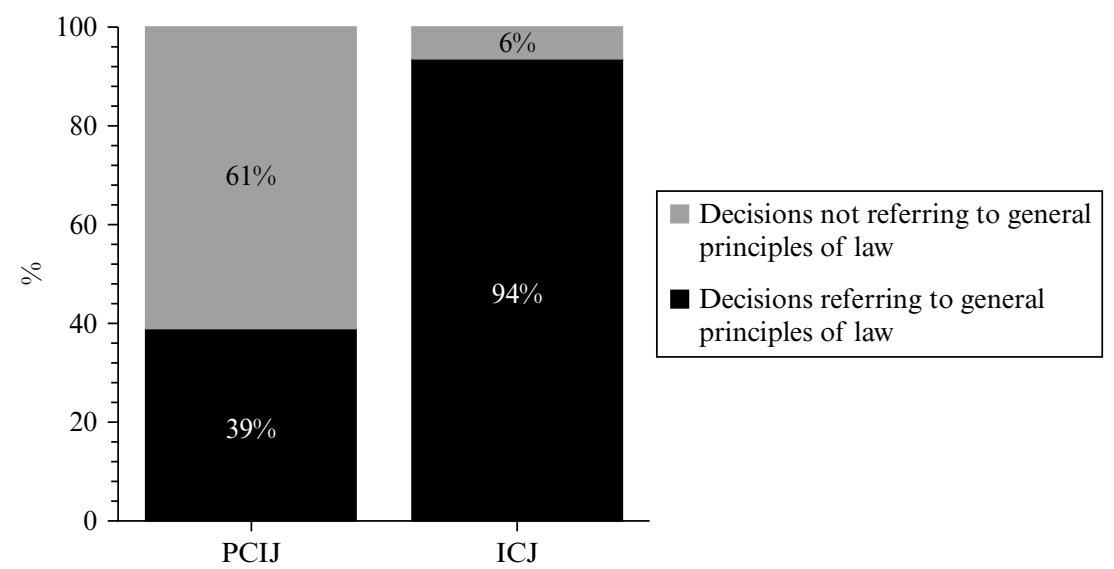

Figure 1.1 Decisions referring to general principles between 1922 and 2018. Orders, whether for provisional measures or compensation (i.e., documents titled 'order'), were not considered as part of the calculation of the total decisions.

The PCIJ (1922-1940) referred to general principles in 38 out of 59 decisions in total (64.4 per cent); the ICJ (1948-2018) referred to general principles in 127 out of the total of 156 decisions ( 81.4 per cent).

\subsubsection{Number of General Principles}

The analysis led to finding that the PCIJ ascertained 64 general principles, while the ICJ relied on 130 general principles. Out of the 130 general principles relied upon by the ICJ, 38 general principles had been previously used by the PCIJ. In total, between 1922 and 2018 both the PCIJ and the ICJ ascertained 156 general principles. (See Figure 1.2)

Company, New York 1943) 611-12 (writing that 'the Court has never professed to draw upon "the general principles of law recognized by civilized nations" in its search for the applicable law'). 


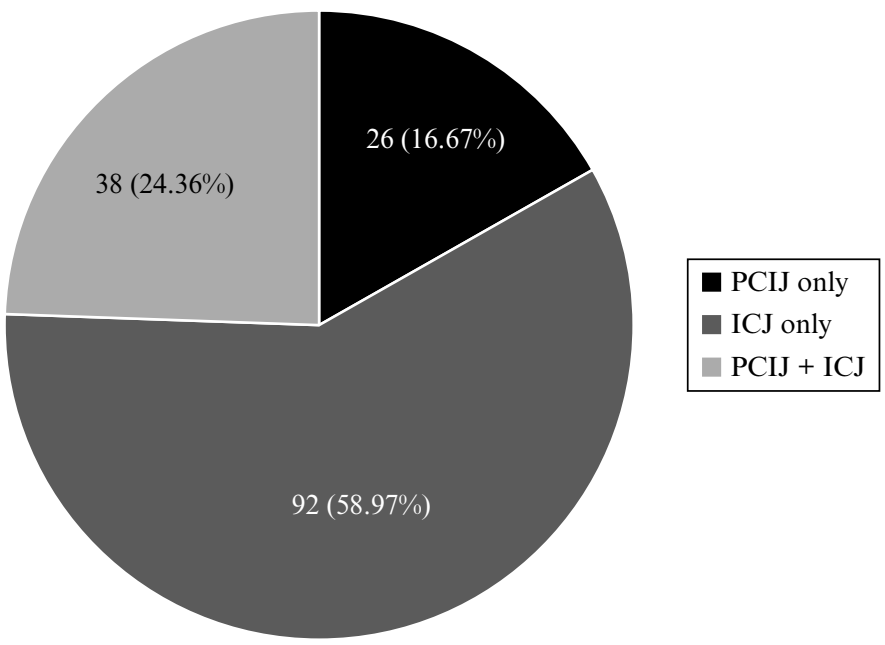

Figure 1.2 Distribution of general principles ascertained from 1922 to 2018 between the PCIJ (1922-1940) and the ICJ (1948-2018)

\subsubsection{Underpinning of General Principles}

Inductively analysing the empirically gathered data dispelled another myth surrounding the underpinning of general principles. It is widely believed that the Court ascertains general principles by relying solely on domestic law. ${ }^{46}$ The research findings, however, show quite the opposite - the Court ascertained only one out of the 156 general principles by relying on domestic law. Several general principles found their basis in international instruments, while the majority of the general principles have a judicial underpinning.

46 Alain Pellet, 'Article 38' in Andreas Zimmerman, Karin Oellers-Frahm, Christian Tomuschat and Christian J. Tams (eds), The Statute of the International Court of Justice: A Commentary (Oxford University Press, Oxford 2012) 766; Mahmoud Cherif Bassiouni, 'A Functional Approach to "General Principles of International Law"' [1990] Mich. J. Int'l L. 779 (noting that this is a 'pragmatic approach'). Cf. Rumiana Yotova, 'Challenges in the Identification of the "General Principles of Law Recognized by Civilized Nations": The Approach of the International Court' [2017] Can. J. Comp. \& Contemp. L. 322; Giorgio Gaja, 'General Principles of Law' [2013] Max Planck Encyclopedia of Public International Law $\$ 32<$ https://opil.ouplaw.com/view/10.1093/law:epil/9780199231690/law-9780 199231690-e1410> accessed 20 August 2019 (noting that '[p]rinciples drawn from municipal laws were applied only with caution by the ICJ'). 
General principles may have domestic, international and/or a judicial underpinning. A general principle was attributed a domestic underpinning when the Court relied on domestic law in ascertaining its existence or content. A general principle was attributed an international underpinning when the Court ascertained its existence of content in international documents, such as General Assembly resolutions, treaties and International Law Commission documents. The third (judicial) underpinning was attributed to those general principles that the Court did not assign any particular document or basis. The Court in ascertaining them did not cite to any external evidence. The existence of these general principles was mostly dependent on the Court's reasoning (hence the name 'judicial' underpinning).

The same general principle can have one or more underpinnings. A general principle that the Court identified in more bases (domestic, international and/or judicial), either in the same decision or over the course of its jurisprudence, was considered to be a general principle with a 'mixed' underpinning. (See Figure 1.3)

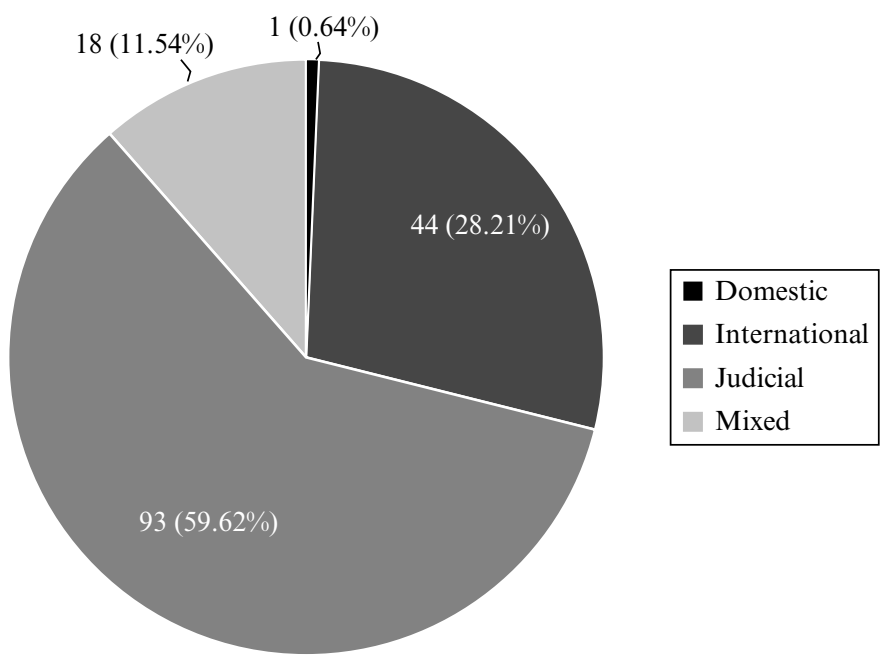

Figure 1.3 Underpinnings of general principles (1922-2018)

\subsubsection{Recurrence of General Principles}

Some experts may question the approach of limiting the research of the Court's use of Article 38(1)(c) to its references to 'principles'. There is some truth in such scepticism because the Court uses the word 'principle' also as a word-filler, which does not lead to an identification of an Article 
38(1)(c) norm (see Step 3 above). However, the Court's repeated reliance on the same 'principle'-norms in more than one decision lends credibility to the initial premise that the Court's references to 'principles' are mostly to general principles within Article 38(1)(c). For example, the Court referred to a general principle that had been ascertained in a previous decision (and created a recurrent general principle) in the 1973 Fisheries Jurisdiction case, when it affirmed that '[it] would normally apply the principle it reaffirmed in its 1950 Advisory Opinion . . . according to which there is no occasion to resort to preparatory work if the text of a convention is sufficiently clear in itself'. ${ }^{47}$

The Court's reliance on 'principle'-norms is not random - the Court often relied on the same norm that it once ascertained as a 'principle' (also if not referred to as a 'principle' in other decisions) in more than one decision. For example, the Court in the 1924 Mavrommatis Palestine Concessions relied on the 'elementary principle of international law that a State is entitled to protect its subjects, when injured by acts contrary to international law committed by another State, from whom they have been unable to obtain satisfaction through the ordinary channels', ${ }^{48}$ or briefly, the general principle of diplomatic protection. In some of its subsequent decisions the Court omitted to mention the word 'principle' when relying on the same norm. For example, in its 1955 Nottebohm case the Court invoked '[d]iplomatic protection and protection by means of international judicial proceedings' ${ }^{49}$ Although describing diplomatic protection as a 'principle' in its 1924 decision but not also in its 1955 decision, the Court relied on the same norm and, therefore, on the same general principle.

The Court's repeated reliance on the same 'principle'-norm in its decisions provided another angle through which general principles may be observed, namely, their recurrence. Recurrence is defined in this research as the repetition of the same general principle in two or more decisions, even if the Court did not use the same wording in describing it.

The findings showed that the majority of the 156 general principles ascertained by the Court between 1922 and 2018 are recurrent. The vast majority of the recurrent general principles appeared in three or more decisions.

47 Fisheries Jurisdiction [1973] I.C.J. [q17] (emphasis added).

48 Mavrommatis Palestine Concessions [1924] P.C.I.J. (A/20) [12] (emphasis added).

49 Nottebohm [1955] I.C.J. 4 [24]. 


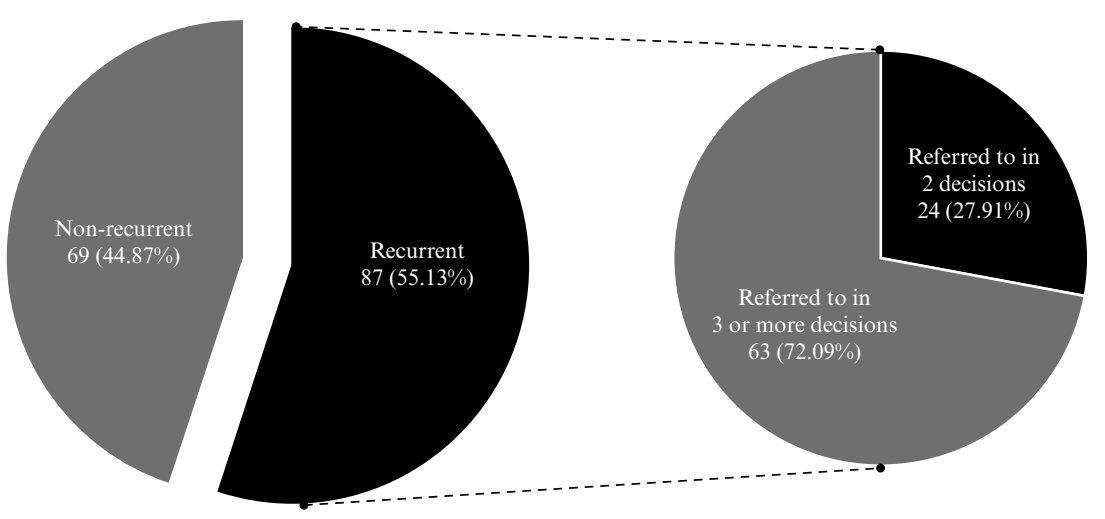

Figure 1.4 Recurrence of general principles (1922-2018). The Court referred to 87 out of 156 general principles in two or more decisions. Sixty-three out of 156 general principles were referred to in three or more decisions.

The most recurrent general principle was res judicata, appearing in 37 decisions. (See Figure 1.4)

\subsubsection{Types of General Principles}

The empirically inductive approach also led to finding a new, third type of general principles, namely, interpretative general principles. Scholars mainly consider general principles to be substantive or procedural. ${ }^{50}$

50 Mahmoud Cherif Bassiouni, 'A Functional Approach to "General Principles of International Law"” [1990] Mich. J. Int'l L. 801 (noting that general principles 'serve a "normative function" in the regulation of State conduct'); Martins Paparinskis, 'General Principles and the Other Sources of International Law: Conclusions' in Mads Andenas, Malgosia Fitzmaurice, Attila Tanzi and Jan Wouters (eds), General Principles and the Coherence of International Law (Brill, Leiden 2019) 119 (referring to Kolb); Przemysław Saganek, 'General Principles of Law in Public International Law' [2017] Polish Y. Int'l L. 249; Clive Parry, The Sources and Evidences of International Law (Manchester University Press, Manchester 1965) 86. Cf. Jan Wouters, Dominic Coppens and Dylan Garaets, 'The Influence of General Principles of Law' in Sanford E. Gaines, Birgitte Egelund Olsen and Karsten Engsig Sørensen (eds), Liberalising Trade in the EU and the WTO (Cambridge University Press, Cambridge 2012) 50 (considering interpretative general principles as a subcategory of procedural general principles of law); Mahmoud Cherif Bassiouni, "A Functional Approach to "General Principles of International Law"' [1990] Mich. J. Int'1 L. 776 (noting that '[t]he 
However, the findings indicate that general principles take on an interpretative role in the Court's jurisprudence that is not to be confused with their substantive or procedural nature. Interpretative general principles do not guide the conduct of States as substantive general principles do; nor do they supplement the Court's rules of procedure as procedural general principles do. Instead, interpretative general principles guide the Court's interpretation and ascertainment of international law applicable to the dispute before the Court. Thus, the Court ascertains substantive, procedural and interpretive general principles. (See Figure 1.5)

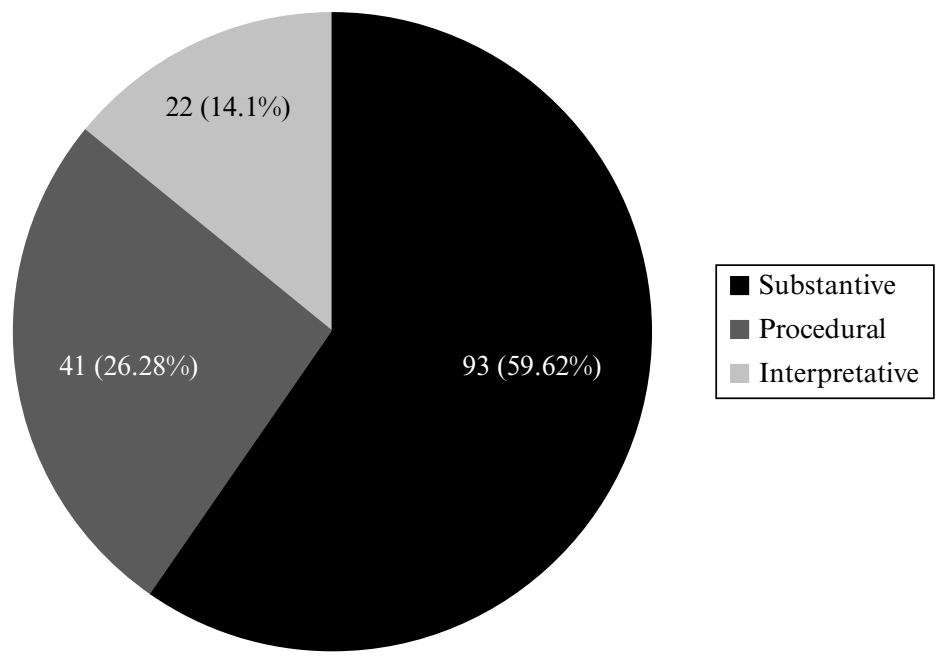

Figure 1.5 Types of general principles (1922-2018)

The difference between substantive, procedural and interpretative general principles is their scope of application and nature. Substantive

extent to which one can resort to "General Principles" for interpretative purposes has never been established'); Jean d'Aspremont, 'What Was Not Meant to Be: General Principles of Law as a Source of International Law' in Riccardo Pisillo Mazzeschi and Pasquale De Sena (eds), Global Justice, Human Rights, and the Modernization of International Law (Springer, Cham 2018) 164 (arguing that interpretative general principles are not a source of international law). But see Thomas Kleinlein, 'Customary International Law and General Principles: Rethinking Their Relationship' in Brian D. Lepard (ed.), Reexamining Customary International Law (Cambridge University Press, Cambridge 2017) 142; Géza Herczegh, General Principles of Law and the International Legal Order (Akadémiai Kiadó, Budapest 1969) 69. 
general principles, as defined in this chapter, are those principles and rules that guide State conduct. Two examples of substantive general principles are that of non-intervention and the prohibition of the use of force.

Procedural general principles apply to States, the Court or the judges and are applied only for the duration of the proceedings before the Court. A procedural general principle is, for example, kompetenz-kompetenz, which provides that the Court has the authority to decide upon its jurisdiction. Another procedural general principle is audi alteram partem (listen to the other side). ${ }^{51}$

Interpretative general principles guide the Court's interpretation and ascertainment of the applicable international law and govern (at least within the framework of the Court's jurisprudence) only the conduct of the Court. Due to another general principle, jura novit curia. (the Court knows the law) ${ }^{52}$ the Court does not rely on States' interpretation of international law when deciding a case. An example of an interpretative general principle is that of effectiveness (also known as $u t$ res magis valeat quam pereat) and the general principle that a legal text should be interpreted in such a way that a reason and a meaning be attributed to every word in the text.

\subsubsection{Type-Underpinning Analysis}

Creating a tangible dataset of general principles enabled comparison of the interaction between the type and the underpinning of general principles. This comparison revealed that the majority of general principles with an international underpinning were substantive; and the majority of general principles with a judicial underpinning were either procedural or interpretative. (See Figure 1.6)

The prevalent underpinning among the general principles is by far the judicial underpinning. Procedural and interpretative general principles share a similar proportion of judicial and international underpinning; domestic underpinning can be traced only to the substantive general principles.

51 Aaron X. Fellmeth and Maurice Horwitz, Guide to Latin in International Law (Oxford University Press, Oxford 2009) 41.

52 Aaron X. Fellmeth and Maurice Horwitz, Guide to Latin in International Law (Oxford University Press, Oxford 2009) 147. 


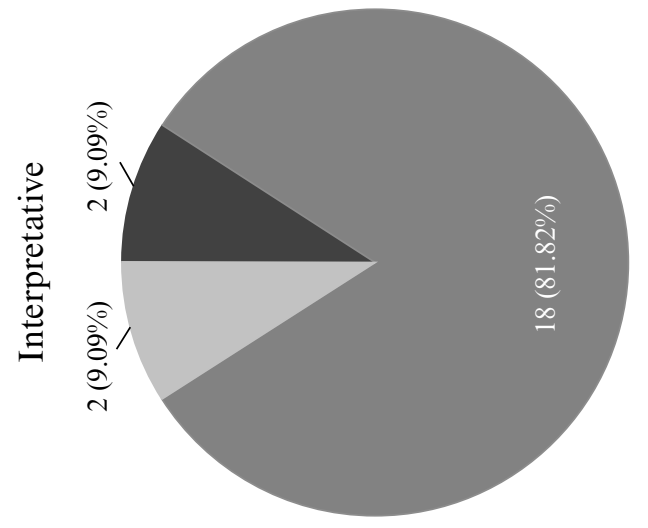

$\frac{1}{5}$
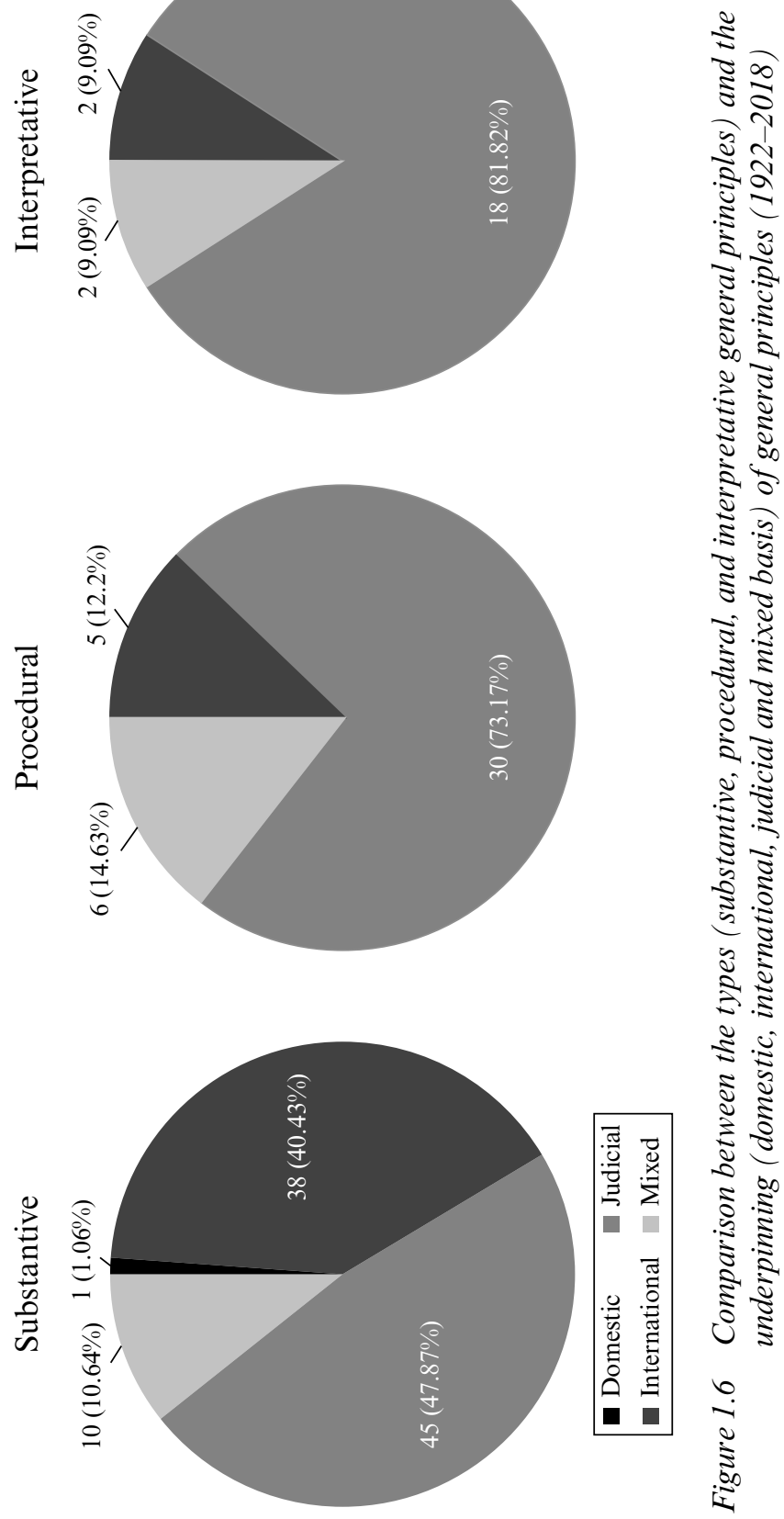


\section{4 'SCIENTIFIC' RESULTS}

The more objective (or 'scientific') approach to the research of general principles inspired more 'scientific' results.

\subsubsection{Cube}

The inductive-empirical analysis inspired the creation of a 'Cube' - a visual model that classifies all general principles under the same umbrella (or within the same 'Cube'). The Cube on its six sides describes the six characteristics that transpired from the research and that each general principle may have. Three characteristics relate to the basis upon which the Court ascertained general principles (underpinning): domestic law, international law and/or judicial authority to decide. The remaining three characteristics describe the type of general principles: substantive, procedural and interpretative. A general principle is usually of one type (there are rare exceptions to this rule) and may have one or more underpinnings. (See Figure 1.7)
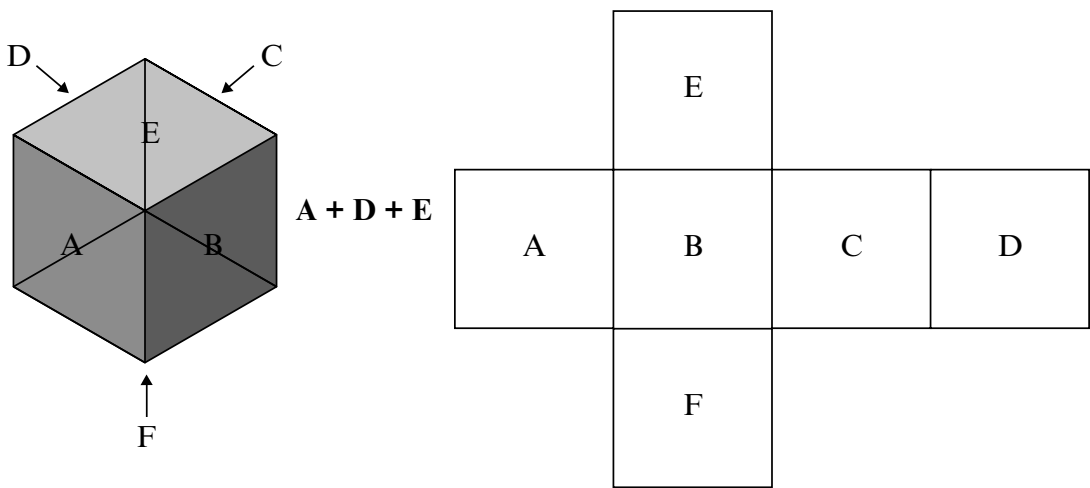

A: Substantive General Principles B: Procedural General Principles C: Interpretative General Principles D: Domestic Underpinning E: International Underpinning F: Judicial Underpinning

Figure 1.7 The Cube with six characteristics. A, B and C stand for the type of general principles: A: substantive, B: procedural and $C$ : interpretative. $D, E$ and $F$ refer to the underpinning: $D$ : domestic underpinning, E: international underpinning and $F$ : judicial underpinning.

Each general principle may be placed in any part of the Cube, depending on its characteristics. For example, a procedural general principle with a judicial underpinning finds its place on the bottom right corner of the Cube. (See Figure 1.8) Similarly, a substantive general principle with both 


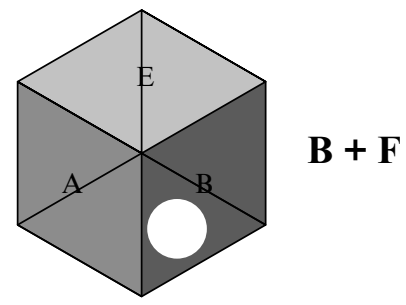

Figure 1.8 Positioning of a procedural general principle with a judicial underpinning within the Cube

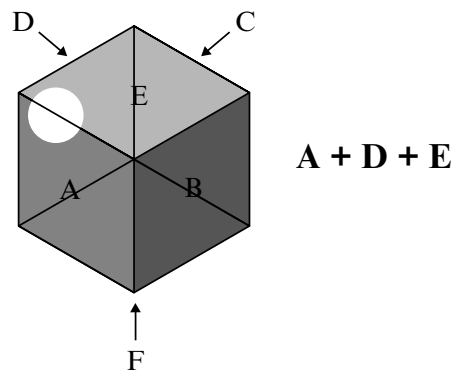

Figure 1.9 Positioning of a substantive general principle with a domestic and international (i.e., mixed) underpinning within the Cube

a domestic and an international underpinning finds its place at the top left corner of the Cube. (See Figure 1.9)

\subsubsection{Worksheet}

Results of the combined empirical research and inductive analysis were gathered in a worksheet. Each general principle was given a number and classified according to its type (i.e., substantive, procedural or interpretative). General principles of each type were further subdivided into topics. For example, substantive general principles were subdivided into 11 topics (the two topics shown on the image below are, for example, the law of treaties and diplomatic and consular law). (See Figure 1.10)

In addition to the types of general principles, the worksheet contains information on the number of decisions that refer to a particular general principle and its underpinning. For example, as the worksheet demonstrates, general principle \#1 (i.e., general principle of res inter alios acta) is a substantive general principle with a judicial underpinning. It was 


\begin{tabular}{|c|c|c|c|c|c|c|c|c|c|c|}
\hline & \multicolumn{3}{|c|}{$\begin{array}{l}\text { Number of } \\
\text { decisions } \\
\text { referring to the } \\
\text { general principle } \\
\text { of law }\end{array}$} & \multicolumn{3}{|c|}{ Type } & \multicolumn{4}{|c|}{ Underpinning } \\
\hline & PCIJ & ICJ & Total & Substantive & Procedural & Interpretative & Domestic & Int'l & Judicial & Total \\
\hline \multicolumn{11}{|c|}{ SUBSTANTIVE GENERAL PRINCIPLES OF LAW } \\
\hline \multicolumn{11}{|c|}{ Law of Treaties } \\
\hline \#1 & 0 & 2 & 2 & $\mathrm{x}$ & & & & & $\mathrm{x}$ & 1 \\
\hline$\overline{H Z}$ & 0 & 1 & 1 & $\mathrm{x}$ & & & & & $\mathrm{x}$ & 1 \\
\hline \#3 & 1 & 0 & 1 & $\mathrm{x}$ & & & & & $\mathrm{x}$ & 1 \\
\hline$\# 4$ & 0 & 1 & 1 & $\mathrm{x}$ & & & & $\mathbf{x}$ & & 1 \\
\hline$\# 5$ & 0 & 1 & 1 & $\mathrm{x}$ & & & & $\mathrm{x}$ & & 1 \\
\hline \#6 & 0 & 2 & 2 & $\mathrm{x}$ & & & & $\mathrm{x}$ & $\mathrm{x}$ & 2 \\
\hline$\# 7$ & 2 & 3 & 5 & $\mathrm{x}$ & & & & $x$ & & $T$ \\
\hline \multicolumn{11}{|c|}{ Diplomatic and Consular Law } \\
\hline$\# 8$ & 0 & 1 & 1 & $\mathrm{x}$ & & & & $x$ & & 1 \\
\hline \#9 & 0 & 1 & 1 & $\mathrm{x}$ & & & & $\mathrm{x}$ & & 1 \\
\hline
\end{tabular}

Figure 1.10 Excerpt of the worksheet of 156 general principles. Listed on the left is the number attributed to each general principle. The number assigned to a general principle is not representative of its importance and does not imply a hierarchy among the general principles

classified as one of the general principles under the topic of the 'Law of Treaties'. Res inter alios acta appears in two ICJ decisions (and is a recurrent general principle) but was not invoked in the PCIJ jurisprudence.

General principle \#6 (i.e., general principle regulating termination of a treaty relationship on account of breach) is also a substantive general principle and is classified under the same topic as general principle \#1. However, unlike \#1, general principle \#6 has two (international and judicial) underpinnings.

General principle \#7 (general principle of rebus sic stantibus) is a recurrent general principle both in the PCIJ and in the ICJ jurisprudence.

\subsubsection{Digest of General Principles}

The worksheet enabled the development of the Digest of General Principles that lists all 156 general principles ascertained by the Court in its 97 year jurisprudence. The Digest is available as part of the author's forthcoming monograph General Principles of Law Recognized by Civilized Nations (1922-2018).

General principles listed in the Digest are classified according to their type (substantive, procedural, interpretative) and into 24 topics. Substantive general principles were classified into 11 topics, procedural into 6 and interpretative into 7 topics.

The name of each general principle (and its identifier number) is fol- 
lowed by its classification and the excerpts of all the Court's decisions in which the general principle appears. Not all excerpts contain the word 'principle'. As explained above, the Court sometimes referred to the same norm it had identified as 'principle' by omitting the prefix 'principle'. All references to the same norm were considered as a reference to a general principle within the meaning of Article 38(1)(c), provided that the norm was mentioned at least once as a 'principle'. (See Figure 1.11)

\begin{tabular}{|c|c|}
\hline \#108 & General principle that question referred to the Court for advisory opinion is \\
\hline & $\begin{array}{l}\text { Type: Procedural } \\
\text { Underpinning: International }\end{array}$ \\
\hline & $\begin{array}{l}\text { Interpretation of Article 3, Paragraph 2, of the Treaty of Lausanne, Advisory Opinion, } 1925 \\
\text { P.C.I.J. (ser.B) No.12 (Nov.21) }\end{array}$ \\
\hline 1925: & $\begin{array}{l}\text { "The notifications to Great Britain and Turkey were further based on the principle laid } \\
\text { down in the Rules of the Court, in accordance with which a question referred to the Court } \\
\text { for advisory opinion is communicated to governments likely to be able to supply } \\
\text { information in regard to it" (at } 8 \text { ). }\end{array}$ \\
\hline
\end{tabular}

Figure 1.11 Sample from the Digest of General Principles of Law (1922-2018). This sample shows general principle \#108 with a description of its characteristics and the excerpt of the Court's decision that refers to this general principle. The emphasis of the word 'principle' was added.

\subsubsection{Formula of the General Principle of Diplomatic Protection}

The empirically inductive analysis and the resulting worksheet and Digest made it possible to observe the evolution of general principles over time. The evolution of any 'principle'-norm within the Court's jurisprudence can be presented in a simple formula. A formula of general principles, created for the purpose of defining its content presents clearly the constituting elements that many have been added across various decisions. The formula below presents the general principle of diplomatic protection as it evolved in the Court's decisions rendered between 1924 and 2012. (See Figure 1.12)

Diplomatic protection is a procedural general principle with a judicial underpinning. It serves the Court in ascertaining whether the State before it has a right to pursue a claim on behalf of its individuals and companies. In other words, diplomatic protection confers to a State the right of standing before an international court where the breach of international obligations has not directly affected the State. Neither the Court's Statute nor its Rules of Procedure provide for this possibility. 


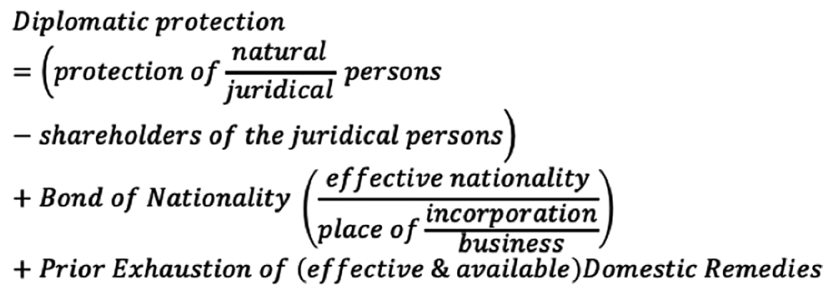

Figure 1.12 Formula of the general principle of diplomatic protection (1924-2012). A related concept - functional protection, which relates to the standing of an international organization in relation to its staff - is for the present purposes omitted from the formula.

Ascertained first in 1924 in Mavrommatis Palestine Concessions as an 'elementary principle of international law', ${ }^{53}$ the Court proceeded to refer to diplomatic protection in 13 decisions, last mentioning it in the 2012 Ahmadou Sadio Diallo case. ${ }^{54}$ The formula that transpired after analysing the Court's 88 years of jurisprudence of considering diplomatic protection is shown in Figure 1.12.

The Court clarified and developed the elements of diplomatic protection over the course of its jurisprudence. For example, one of its elements (i.e., the 'bond of nationality') was clarified in the Nottebohm, Anglo-Iranian Oil Co. and Barcelona Traction cases. In Nottebohm, the Court discussed the requirement of the bond of nationality in relation to the nationality of an individual, ${ }^{55}$ whereas in the Anglo-Iranian Oil Co. and Barcelona Traction cases the Court considered the nationality of companies and

53 Mavrommatis Palestine Concessions [1924] P.C.I.J. (A/2) [12]. The International Law Commission refers to Mavrommatis Palestine Concessions in its commentary to article 1 of the draft articles on diplomatic protection. See e.g., International Law Commission, Draft Articles on Diplomatic Protection with Commentaries (U.N. Doc. A/61/10, 2006) 25.

54 See Mavrommatis Palestine Concessions [1924] P.C.I.J. (A/2) [11-2]; Factory at Chorzów [1928] P.C.I.J. (A/17) [27-8]; Serbian Loans [1929] P.C.I.J. (A/20); Panevezys-Saldutiskis Railway [1939] P.C.I.J. (AB/76) [16]; Reparation for Injuries Suffered in the Service of the United Nations [1949] I.C.J. [186-7]; Anglo-Iranian Oil [1952] I.C.J. [112] [115]; Nottebohm [1955] I.C.J. [20-1] [24]; Barcelona Traction, Light and Power Company, Limited [1970] I.C.J. [\$36] [\$37] [\$88]; LaGrand [2001] I.C.J. [ๆ42] [ๆ77]; Avena and Other Mexican Nationals [2004] I.C.J. [ๆ40]; Armed Activities in the Territory of the Congo [2005] I.C.J. [9330] [9333]; Ahmadou Sadio Diallo [2007] I.C.J. [939] [961] [9甲87-9] [91] [93]; Ahmadou Sadio Diallo [2012] I.C.J. [ๆ57].

55 Nottebohm [1955] I.C.J. [13] [21-3] [26]. 
shareholders. ${ }^{56}$ The Court added the element of the prior exhaustion of domestic remedies in the Interhandel case. ${ }^{57}$

Visualising the constituting elements of each general principle (and other international norms) as for example through formulas is beneficial in dispelling any potential misunderstandings on the content and role of a particular norm. Encapsulating general principles in objectively verifiable and transparent formulas may contribute to less disagreements and more constructive scholarly debates on the Article 38(1)(c) source.

\subsection{CONCLUSION}

The inductive-empirical analysis of the Court's 215 decisions (up to 2018) yielded several innovative results, some of which directly contradict the long-established doctrinal theories on the nature and function of general principles.

As the great physicist Albert Einstein observed, '[w] hether you can observe a thing or not depends on the theory which you use. It is the theory which decides what can be observed' ${ }^{5}{ }^{5}$ In other words, the theory (i.e., the initial idea and selection of the research approach) has a major impact on the ensuing results. And vice versa, empirical research provides a fertile ground for the emergence of new theories. In the case of the research at hand, new theories relative to general principles that emerged concern their nature, definition, and the relationship with other sources of international law, to name a few.

There is a significant gap between scholarly opinions on general principles and the empirical findings. Not only is doctrine divided on the very fundamental questions concerning Article 38(1)(c), but it can be rarely reconciled with the findings of the present research. One can only speculate what the reasons for such discrepancies between the doctrine and empirical findings resulting from the Court's jurisprudence are.

Most doctrinal works on general principles do not disclose their method of ascertaining and analysing general principles. Are researchers relying on judicial precedents or decisions of international organizations? If so, do scholars satisfy their research curiosity by considering only a handful

\footnotetext{
56 Anglo-Iranian Oil [1952] I.C.J. [109-12]; Barcelona Traction, Light and Power Company, Limited [1970] I.C.J. [ศๆ70-2].

57 Interhandel [1959] I.C.J. [27].

58 Edward Fullbrook, 'To Observe or Not to Observe: Complementary Pluralism in Physics and Economics' [2012] Real-world Econ. Rev. $20<$ http:// www.paecon.net/PAEReview/issue62/Fullbrook62.pdf> accessed 31 January 2019.
} 
of the available material or are their assessments and assertions based on a comprehensive research? Do scholars forego the primary sources (judicial decisions) and rely solely on other (potentially selected) scholarship in creating new or recycling 'old' theories on general principles?

Doctrine, however unhelpful it may be on the topic of general principles, cannot be completely discarded with if one wishes to put forward a sustainable and serious theory of international law and its sources. Although scholarship did not play a significant role in empirically gathering and inductively analysing the Court's reliance on general principles, scholarly opinion did provide a welcome backdrop for the emergence of new theories relative to this source of international law.

Transparency and legal predictability in ascertaining the sources of international law are crucial in ensuring legal certainty and securing the international community's compliance with international law. Theory does not stand in the way of more objective results - dogmatic reliance on doctrine in creating or developing these theories, without considering their practical application, does. 